\title{
Can leaf area in rice be defined by a mathematical model? ${ }^{1}$
}

\author{
Bruna San Martin Rolim Ribeiro ${ }^{2 *} \mathbb{D}$, Michel Rocha da Silva ${ }^{3}$, Gean Leonardo Richter ${ }^{3}$, Giovana Ghisleni Ribas ${ }^{2}$, \\ Nereu Augusto Streck ${ }^{4}$, Alencar Junior Zanon ${ }^{4}$
}

10.1590/0034-737X201966030005

\begin{abstract}
The goal of this study was to define an empirical model to calculate the leaf area in rice from linear leaf measure in genotypes used by farmers in Brazil. Through the leaf dimensions it is possible to identify the final crop yield from the LAI. Therefore, the leaves shape is closely related to the production of photoassimilates that will be converted into grain yield. Field experiments were carried out in four counties of Rio Grande do Sul with twelve-three varieties of rice in four growing seasons. We measured the length and width of leaves to construct the model. The relationship between leaf area and linear dimensions was shaped using a linear model for each genotype, and general model grouping all genotypes. The model accuracy was measure following statistics: Root Mean Square Error, BIAS, modified index of agreement and coefficient $r$. The non-destructive method for individual leaves was appropriate for estimating the leaf area in rice. Moreover, the general equation was estimated and can be used for all modern genotypes of rice in Brazil.
\end{abstract}

Keywords: Oryza sativa, leaf area index, non-destructive method, linear dimensions.

\section{INTRODUCTION}

Rice (Oryza sativa L.) is a staple crop, feeding three billion people worldwide (Espe et al., 2016). Due to the increase of the world population, it is necessary to invest in research and technology transference aiming to reduce the yield gap in food crops observed between yield obtained at research stations and by farmers yield (Espe et al., 2016, Ribas et al., 2017). In this context, basic studies on crop growth and development for actual rice cultivars in Brazil, the greatest rice producer outside Asian continent, are necessary (Ribas et al., 2017).

The major rice production system in Brazil is under flood irrigation, which means that the water is a nonlimiting factor and the temperature and solar radiation are the main meteorologics elements that determine the flooded rice yield potential. Leaves are the plant organ responsible for intercepting the solar radiation for photosyntesis, therefore the larger the leaf area, more solar radiation is intercepted and higher the yield potential (Van Ittersum et al., 2013, Taiz \& Zieger, 2013). Leaf area index (green leaf area per unit of soil area) may be calculated throught leaf blade size (Tanaka \& Kawano, 1965 and Richter et al., 2014).

There are two methods to define leaf area which are classified in destructive or non-destructive (Marshall, 1986). The destructive methods are based on the removal of leaves from the plant, and although it is the only way to determine the actual leaf area, it may be an impractical approach when the sample number is limited, as in plant breeding studies. In non-destructive methods, LAI determination can be performed by optical instruments, which allows to evaluate the same plant throughout the growing season, and also by satellite images to larger

\footnotetext{
Submitted on May 09th, 2019 and accepted on May 31st, 2019

This is a part of the first author's course work.

${ }^{2}$ Universidade Federal de Santa Maria, Programa de Pós Graduação em Engenharia Agrícola, Santa Maria, Rio Grande do Sul, Brazil. brunasanmartinrolim@gmail.com: giovana.ghisleni@hotmail.com

${ }^{3}$ Universidade Federal de Santa Maria, Programa de Pós Graduação em Agronomia, Santa Maria, Rio Grande do Sul, Brazil. michelrs@live.com; geanleonardorichter@gmail.com

${ }^{4}$ Universidade Federal de Santa Maria, Professor no Departamento de Fitotecnia, Santa Maria, Rio Grande do Sul, Brazil. alencarzanon@hotmail.com; nstreck2@yahoo.com.br

* Corresponding author: brunasanmartinrolim@gmail.com
} 
areas (Jin et al., 2017, Hirooka et al., 2018). For some species, such as forest, the instrument-determined LAI is smaller than actual LAI measured directly in the plant (Stenberg et al., 1994; White et al., 2000). For the rainfed rice crop, the use of instruments such as LAI-2200, present LAI estimates close to the real (Xiao et al., 2002, Liu et al., 2018). However, the performance of methods that use vegetation index is affected by the saturation point, one of the major limitations this technique, and in advanced crop stages, where the leaf area index reaches its maximum value, the reflectance can be affected by leaves overlap ( Brantley et al., 2011). In addition to these limitations, the equipment required to carry out this evaluation are expensive (Liu et al., 2018). However, the non-destructive methods where measurements are made directly in the plant without leaves removal, allows us to allows the evaluation of the same plant during the growing season, and evaluate the LAI evolution during the crop growth, besides being cheaper, faster and less labor intensive (Adami et al., 2008 ).

Studies with other crops like sunflower (Maldaner et al., 2009), canola (Cargnelutti Filho et al., 2015), gladiolus (Schwab et al., 2014) and soybean (Richter et al., 2014) have shown viability to estimate leaf area through nondestructive methods, by measuring leaf blade size. For Rice, some studies performed in 1960's and 1970's in India and Philippines, developed models for leaf area estimation through linear dimensions (Bhan \& Pande, 1966, Palaniswamy \& Gomez 1974). However, these studies were performed for old semi-dwarf japonica cultivars, grown in tropical environment with decumbent leaves. Current rice cultivars grown in Brazil present a distinct plant architecture, with shorter and narrower leaves, and greater yield potential, which indicates a need to review these non-destructive models to identify the rice LA. The goal of this study was to define an empirical model to calculate the leaf area in rice from linear leaf measure in genotypes used by farmers in Brazil.

\section{MATERIALAND METHODS}

Field experiments were conducted in a randomized block design in four locations in Rio Grande do Sul State, Brazil, during four growing seasons (2013/2014, 2014/2015, 2015/2016, 2016/2017): Santa Maria (29 $43^{\circ} \mathrm{S}, 5^{\circ} 43^{\prime} \mathrm{W}$, altitude: $95 \mathrm{~m})$, Restinga Seca $\left(29^{\circ} 48^{\prime} \mathrm{S}, 53^{\circ} 22^{\prime} \mathrm{W}\right.$, altitude: $49 \mathrm{~m})$, Cachoeirinha $\left(29^{\circ} 57^{\prime} \mathrm{S}, 51^{\circ} 5^{\prime} \mathrm{W}\right.$, altitude: $\left.17 \mathrm{~m}\right)$, and Itaqui ( $29^{\circ} 07^{\prime} \mathrm{S}, 56^{\circ} 33^{\prime} \mathrm{W}$, altitude: $\left.57 \mathrm{~m}\right)$ (Figure 1$)$. The climate is subtropical humid and soil varies according to location, with Typic Albaqualf and Typic Plinthaqualf, representing the majority of soil types cultivated with flooded rice in Rio Grande do Sul. Ten modern conventional cultivars (Puitá INTA CL, BRS Pampa, BRS
Jaçana, IRGA 424 RI, IRGA 428, IRGA429, IRGA 424, IRGA 430, Guri INTA CL and BRS Catiana) and three hybrids (Inov CL, QM 1010 CL and Prime CL) were used. These cultivars represent the range of maturation groups currently grown in Brazil. Also, two old conventional cultivars were used, Bluebelle and EEA 406, which represent $50 \%$ of the total rice area sowed in Rio Grande do Sul during the 1970's (Silveira, 1985) (Table 1).

To estimate the relationship between leaf linear dimensions and leaf area, 50 leaves with different sizes were sampled from lower, medium and upper parts of the canopy for each cultivar throughout the rice development cycle (Figure 2).

We collected 50 leaves, where we used 25 leaves to make the calibration and the other 25 leaves to the validation. We used a ruler to measure the length and width, after that the leaves were scanned by resolution scanner 300 dpi resolution scanner. Scanned leaf area (LA) was calculated with the Quant software, version 1.0.2. A linear model was fitted (Equation 1) through the relationship between each leaf dimension (length $\mathrm{x}$ width) and scanned leaf area for each cultivar. Also, a general equation (grouping all conventional and hybrid rice cultivars) was estimated, which may be used to estimate leaf area for new cultivars. We forced the linear regression through the origin, i.e. the linear coefficient was zero (Fagundes et al., 2009, Richter et al., 2014, Schwab et al., 2014):

$L A=a .(L . W)$

where LA is leaf area $\left(\mathrm{cm}^{2}\right), \mathrm{L}$ is leaf length $(\mathrm{cm}), \mathrm{W}$ is the largest leaf blade width $(\mathrm{cm})$ and $\mathrm{a}$ is the angular coefficient or the slope of the linear regression.

The performance of the fitting approach of equation 1 for cultivar specific and general models, were evaluated using the statistics: Root Mean Square Error (RMSE) (Janssen \& Heuberger 1995), modified agreement index (d1) (Willmott et al., 1985), BIAS index (Leite \& Andrade 2002), and correlation coefficient (r) (Samboranha et al., 2013).

$$
\begin{aligned}
& \text { RMSE }=\left[\Sigma\left(S_{i}-O_{i}\right)^{2} \mathrm{n}^{-1}\right]^{0,5} \\
& d 1=1-\left[\Sigma \mid S_{i}-O_{i}\right] \cdot\left[\Sigma\left(\left|S_{i}-\hat{\mathrm{O}}\right|\right)+\left(\left|O_{i}-\hat{\mathrm{O}}\right|\right)\right]^{-1} \\
& \text { BIAS }=\left(\Sigma S_{i}-\Sigma O_{i}\right) \cdot\left(\Sigma O_{i}\right)^{-1} \\
& \left.r=\Sigma\left(O_{i}-\hat{\mathrm{O}}\right)\left(S_{i}-S\right) \cdot\left\{\left[\Sigma\left(O_{i}-\hat{\mathrm{O}}\right)^{2}\right]\left[\Sigma S_{i}-S\right)^{2}\right]\right\}^{-0,5}
\end{aligned}
$$

In equations 2, 3, 4 and 5, $\mathrm{Si}$ is the estimated $\mathrm{LA}\left(\mathrm{cm}^{2}\right.$ leaf $\left.{ }^{-1}\right)$, Oi is the observed LA $\left(\mathrm{cm}^{2} l e a f^{-1}\right)$ and $n$ is the number of observations.

The RMSE express model errors, therefore as much close zero, better is the model performance (Janssen \& Heuberger, 1995). For the d1 index (Willmott et al., 1985), 
the closer to 1 the better the model concordance. The BIAS index gives the deviation between estimated and observed data (Leite \& Andrade, 2002), which indicates the model tendency to underestimate or overestimate the observed data. A correlation coefficient (r) shows how dispersal is estimated from observed data, wherein closer to one indicates a good correlation (Samboranha et al., 2013).

For cultivars IRGA 424 RI, BRS Pampa, Guri INTA CL and Puitá INTA CL LAI determination (Equation 6), 20

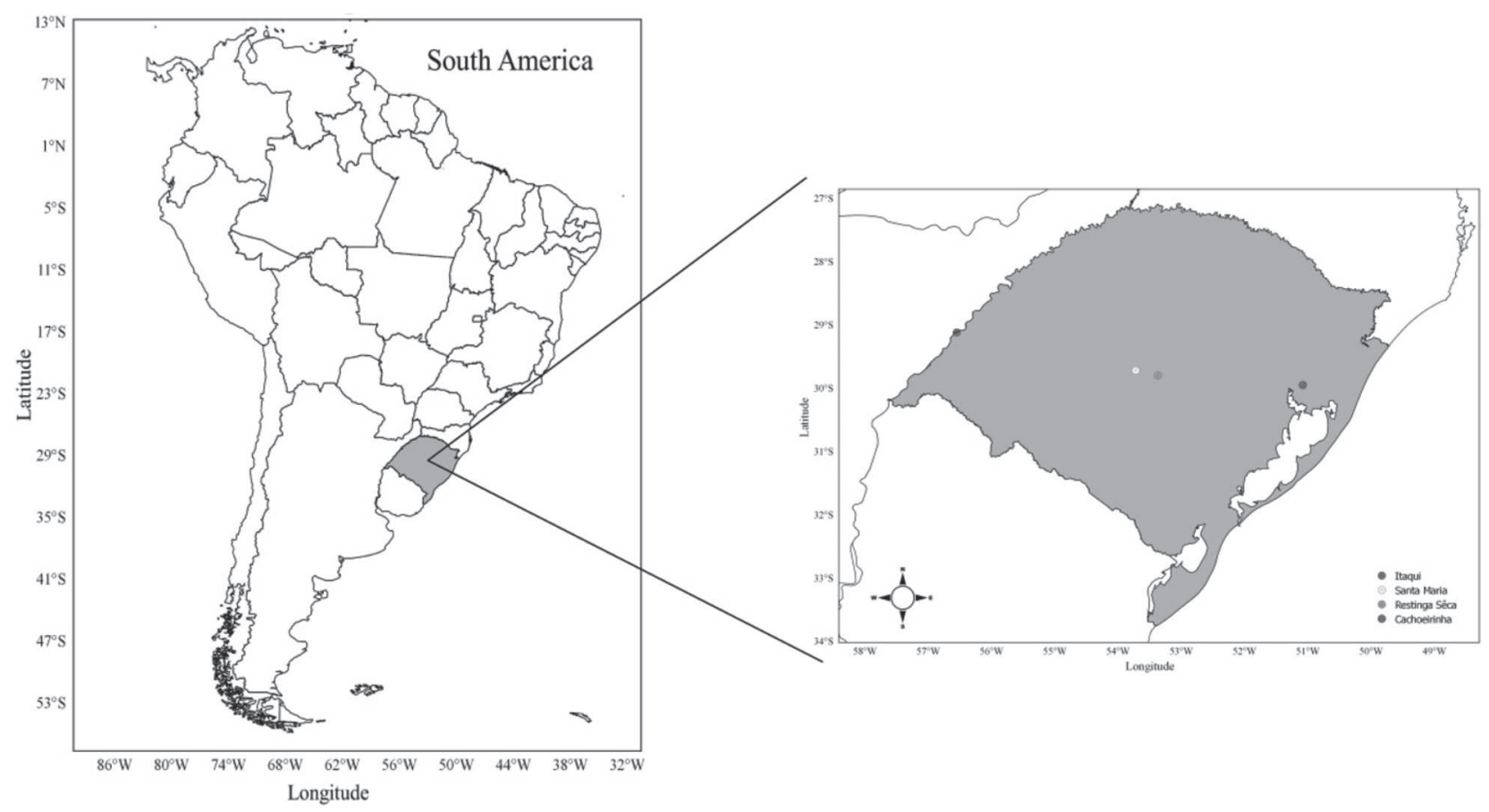

Figure 1: Trials location in Rio Grande do Sul.

Table 1: The growing seasons in which the experiments were conducteds (2013/14,2014/15, 2015/16 e 2016/17) at four locations in Rio Grande do Sul, Brazil

\begin{tabular}{|c|c|c|c|}
\hline Experimental site & Cultivars & Maturity group & Sowing date range \\
\hline $\begin{array}{l}\text { Santa Maria } \\
\text { Cachoeirinha }\end{array}$ & Inov CL & Early & $2(03 \mathrm{Dec}-27 \mathrm{Oct})$ \\
\hline Santa Maria & Prime CL & Early & 1 ( 27 Oct) \\
\hline $\begin{array}{l}\text { Itaqui } \\
\text { Restinga Sêca } \\
\text { Cachoeirinha }\end{array}$ & Puitá INTA CL & Early & $4(26$ Nov -01 Oct -9 Nov -03 Dec $)$ \\
\hline Cachoeirinha & BRS Pampa & Early & 3 (01 Oct - 9 Nov - 03 Dec) \\
\hline Cachoeirinha & Bluebelle & Early & 1 (04 Nov) \\
\hline $\begin{array}{l}\text { Itaqui } \\
\text { Restinga Sêca }\end{array}$ & IRGA 428 & Early & 1 (13 Nov) \\
\hline Santa Maria & IRGA 424 & Early & $3(3 \mathrm{Dec}-20 \mathrm{Oct}-28 \mathrm{Oct})$ \\
\hline $\begin{array}{l}\text { Santa Maria } \\
\text { Cachoeirinha }\end{array}$ & QM $1010 \mathrm{CL}$ & Intermediate & $4(03 \mathrm{Dec}-03 \mathrm{Dec}-27 \mathrm{Oct}-28 \mathrm{Oct})$ \\
\hline Cachoeirinha & IRGA 424 RI & Intermediate & 3 (01 Oct - 09 Nov - 03 Dec) \\
\hline Cachoeirinha & IRGA 429 & Intermediate & $1(21$ Nov $)$ \\
\hline Cachoeirinha & IRGA 430 & Intermediate & $1(21$ Nov ) \\
\hline Cachoeirinha & Guri INTA CL & Intermediate & 3 (01 Oct - 09 Nov - 03 Dec $)$ \\
\hline Cachoeirinha & BRS Jaçanã & Intermediate & $1(01 \mathrm{Oct})$ \\
\hline Cachoeirinha & EEA 406 & Intermediate & 1 ( 04 Nov) \\
\hline Cachoeirinha & BRS Catiana & Late & 3 (01 Oct - 09 Nov - 03 Dec $)$ \\
\hline
\end{tabular}


leaves were collected in R1 (panicle differentiation), R4 (anthesis) and R9 (physiological maturity), in three sowing dates in Cachoeirinha during the 2015/16 growing season. In each sampling, length and widest width were measured, and then leaves were oven dried at $65{ }^{\circ} \mathrm{C}$. Moreover, at these stages, above ground matter was collected and separated into leaves, stems, senescent leaves and panicles in $0.51 \mathrm{~m}^{2}$ area, then oven dried at $65{ }^{\circ} \mathrm{C}$ and weighted. LAI was calculated by the relationship between the leaf dry mass and measured area, shown below:
$L A I=\left((\right.$ LDM.LA $) \cdot$ Weight $^{-1} \cdot(\text { Area } . \text { Coefficient })^{-1}$

where LDM is the leaf dry matter, LA represent the leaf area, Weight is the 20 leaves dry matter, Area is the collected area of LDM and Coefficient refers to specific and general coefficient.

The specific and general LA equations were validated comparing the observed and simulated LAI of four cultivars (IRGA 424 RI, BRS Pampa, Puitá INTA CL, Guri INTACL) in three sowing dates (10/01/2015, 11/09/2015, 12/03/2015) in Cachoerinha, RS, Brazil.
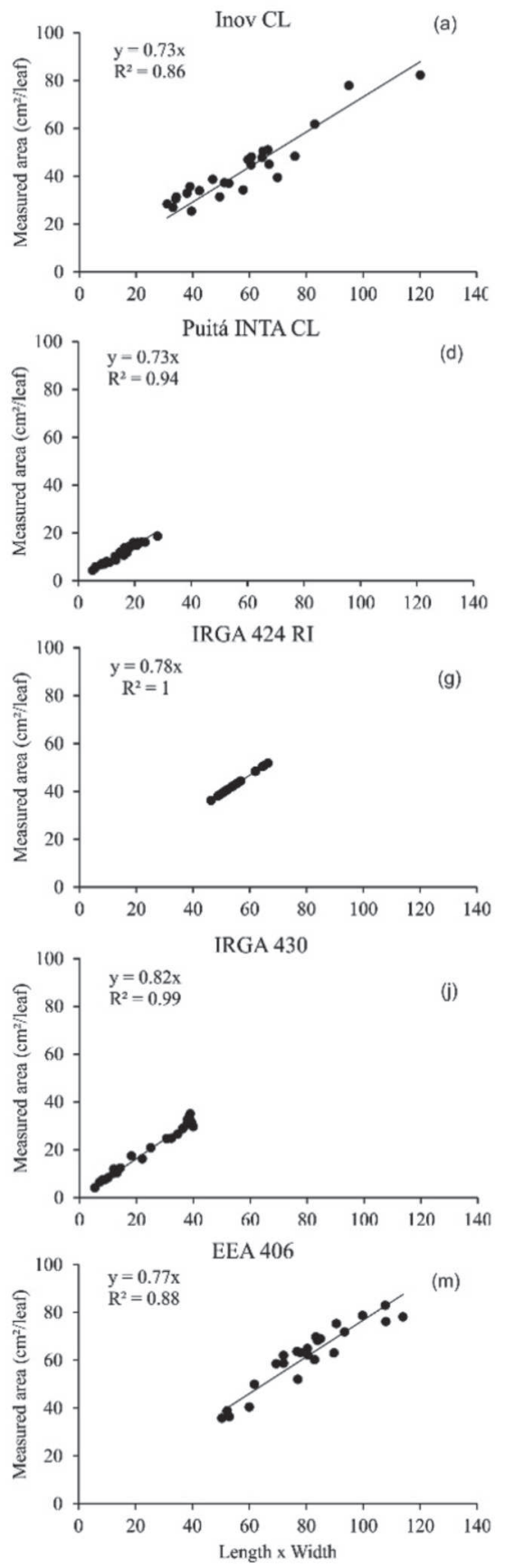
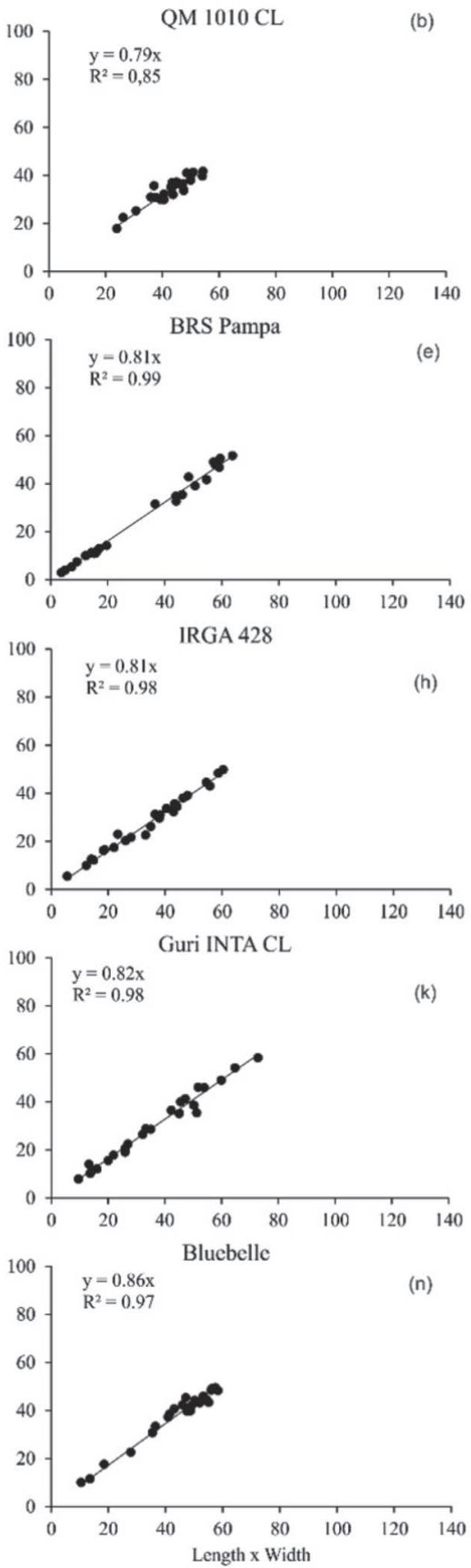
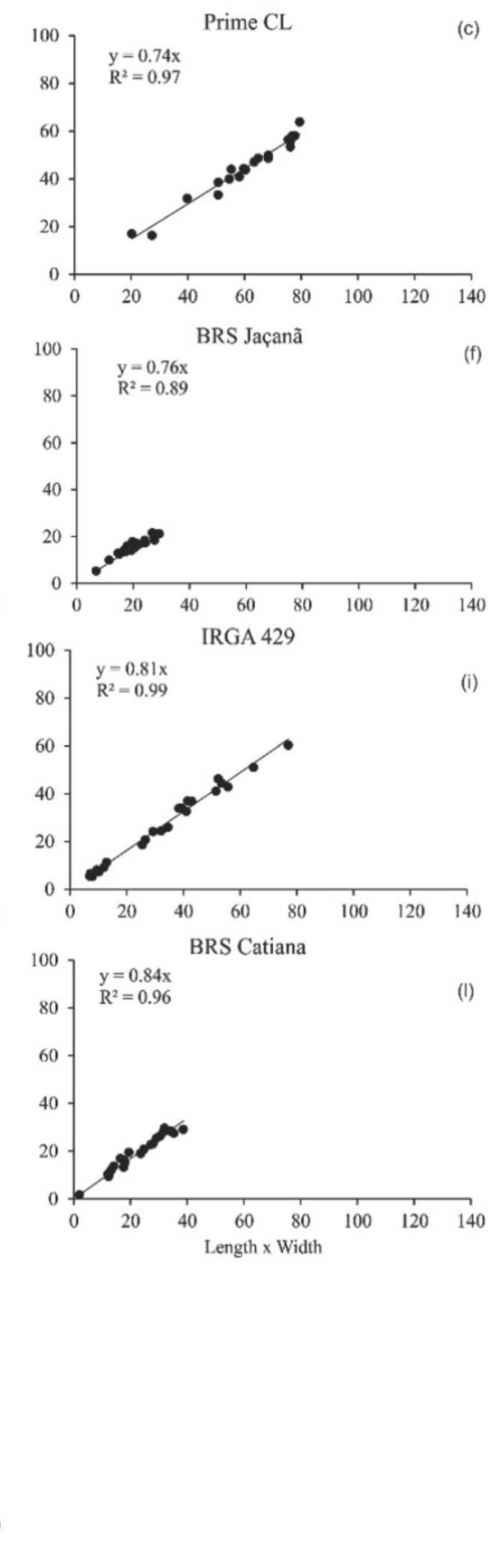

Figure 2: Relationship between leaf area obtained with the software Quant and leaf area obtained from leaf dimensions (maximum length and width) of individual leaves of hybrid rice cultivars (a, b, c) and conventional rice cultivars (d, e, f, g, h, I, j, k, l, m, n) of rice. Cultivar specific equations are presented in each panel.

Rev. Ceres, Viçosa, v. 66, n.3, p. 191-199, mai/jun, 2019 


\section{RESULTS AND DISCUSSION}

Of 700 leafs used in the model construction, the hybrids and the old cultivars were the ones that presented similar size, an important feature used by rice breeding programs and is one of the components that determines crop yield (Yang et al., 2018). The mean leaf length ranged from 9.9 to $48 \mathrm{~cm}$ and the width from 0.47 to $1.31 \mathrm{~cm}$ for the conventional cultivars. Now, for hybrid and old cultivars, the minimum value both from length as for width of leaf, was superior to the conventional cultivars. The mean length of hybrid leaves ranged from 19.5 to $49.9 \mathrm{~cm}$ and the mean width from 0.96 to 1.80 , for the old cultivars the mean length was from 17.2 to 53.1 and the mean width from 0.90 to $2.05 \mathrm{~cm}$. The collections were realized since V3 until R9 and the different extrapolations of plants, what explains a big variety on leaves size and also the model capacity of being used to adjust the leaf area in any development phase of the culture (Figure 3).
The linear regression coefficient $\left(\mathrm{R}^{2}\right)$ used to estimate the angular coefficient "a" (Equation 1$)$ were high $\left(\mathrm{R}^{2} \mathrm{e}\right.$ " $0,85)$, showing that the method is appropriate for simulating LA for all cultivars. There was a slight variation in angular coefficient, ranging from 0.73 to 0.86 (Figure 4), indicating the possibility to use the general equation (LA $\left.=0.78(\mathrm{~L} . \mathrm{W}), \mathrm{R}^{2}=0.97\right)$. The values of linear regression coefficient found in this study are close to those already found for trees and grasses, such as Tectonas grandis $\left(\mathrm{R}^{2}\right.$ $=0.88$ ) Braga et al. (2018).

The RMSE ranged from 0.98 to $5.16 \mathrm{~cm}^{2}$ leaf $^{-1}$ in specific equation and from 1.24 to $4.72 \mathrm{~cm}^{2}$ leaf $^{-1}$ for the general equation, that shows good capability in estimating leaf size (Figure 5).

These RMSE values were less than those found for gladiolus (6.23 a $10.42 \mathrm{~cm}^{2}$ leaf $^{-1}$ ) (Schwab et al. 2014), which leaves shape are lanceolate, similar to rice leaves. For soybean, which has a trifoliate leaf, Bakhshandeh et

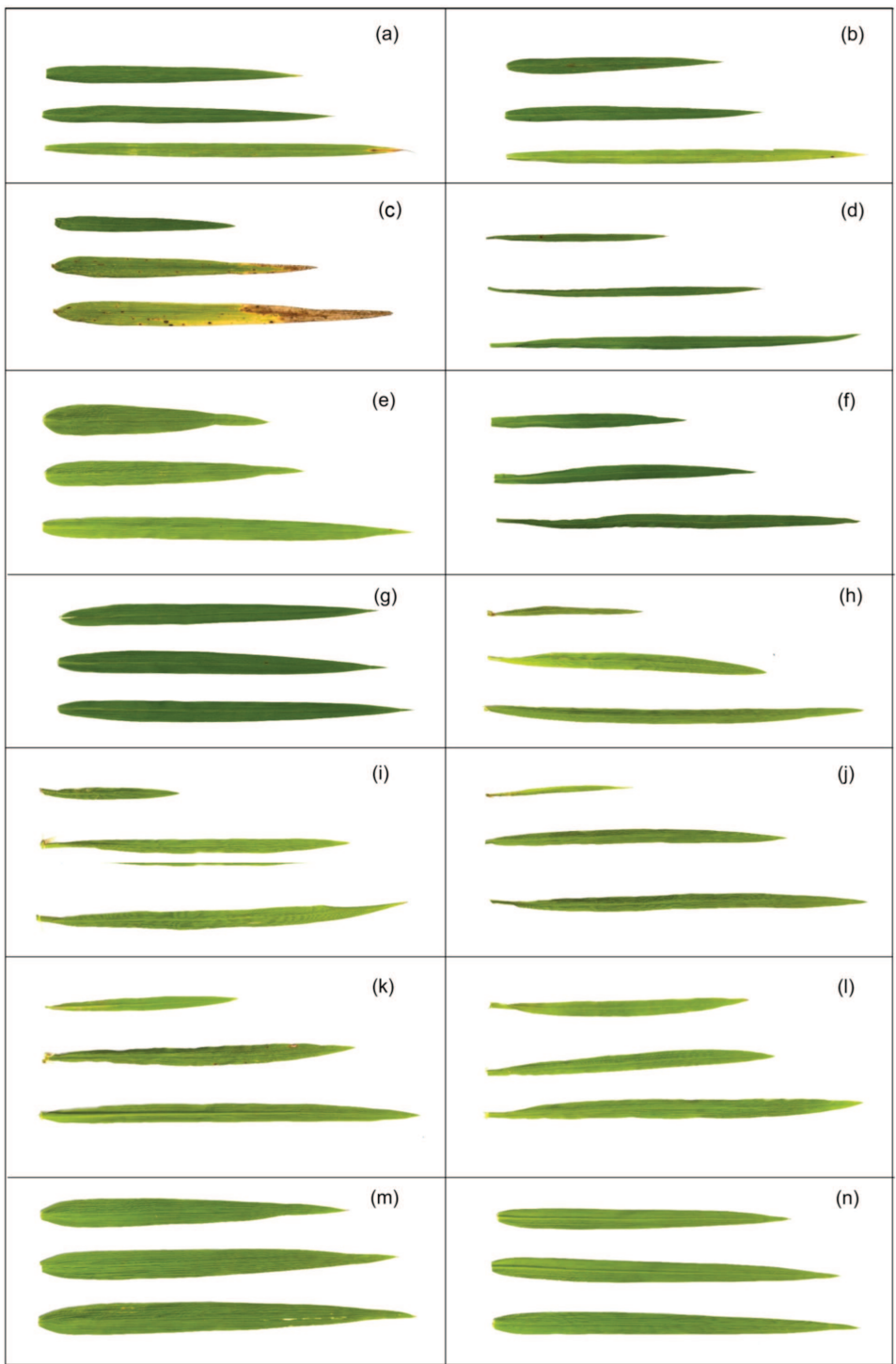

Figure 3: Leaf size of hybrids (a, b, c) and conventional rice cultivars (d, e, f, g, h, i, j, k, 1, m, n). 
al. (2011) found RMSE from 7.33 to $9.22 \mathrm{~cm}^{2}$ leaf $^{-1}$ and Richter et al. (2014) found RMSE from 6.48 to $16.92 \mathrm{~cm}^{2}$ leaf ${ }^{-1}$.

Statistics conform the good model performance (Table 2). For Inov CL hybrid and IRGA 424 RI, IRGA 429 and EEA 406 cultivars, d1 statistic shows a higher fulfillment using the general equation. For IRGA 424 RI, BIAS showed a higher fulfillment using the general equation, and for $r$ index the higher fulfillment was found for Inov CL hybrid using the general equation. The statistics RSME, d1, BIAS and $\mathrm{r}$ showed that is possible to use the general equation to estimate leaf area for other rice cultivars. Similar errors between specific equations and general equations (Table 2) are plausible, as the leaf shape is similar among the cultivars.

There was a slight difference between LAI estimated with the general and the specific equations (Figure 5). The equations presented similar LAI evolution during the
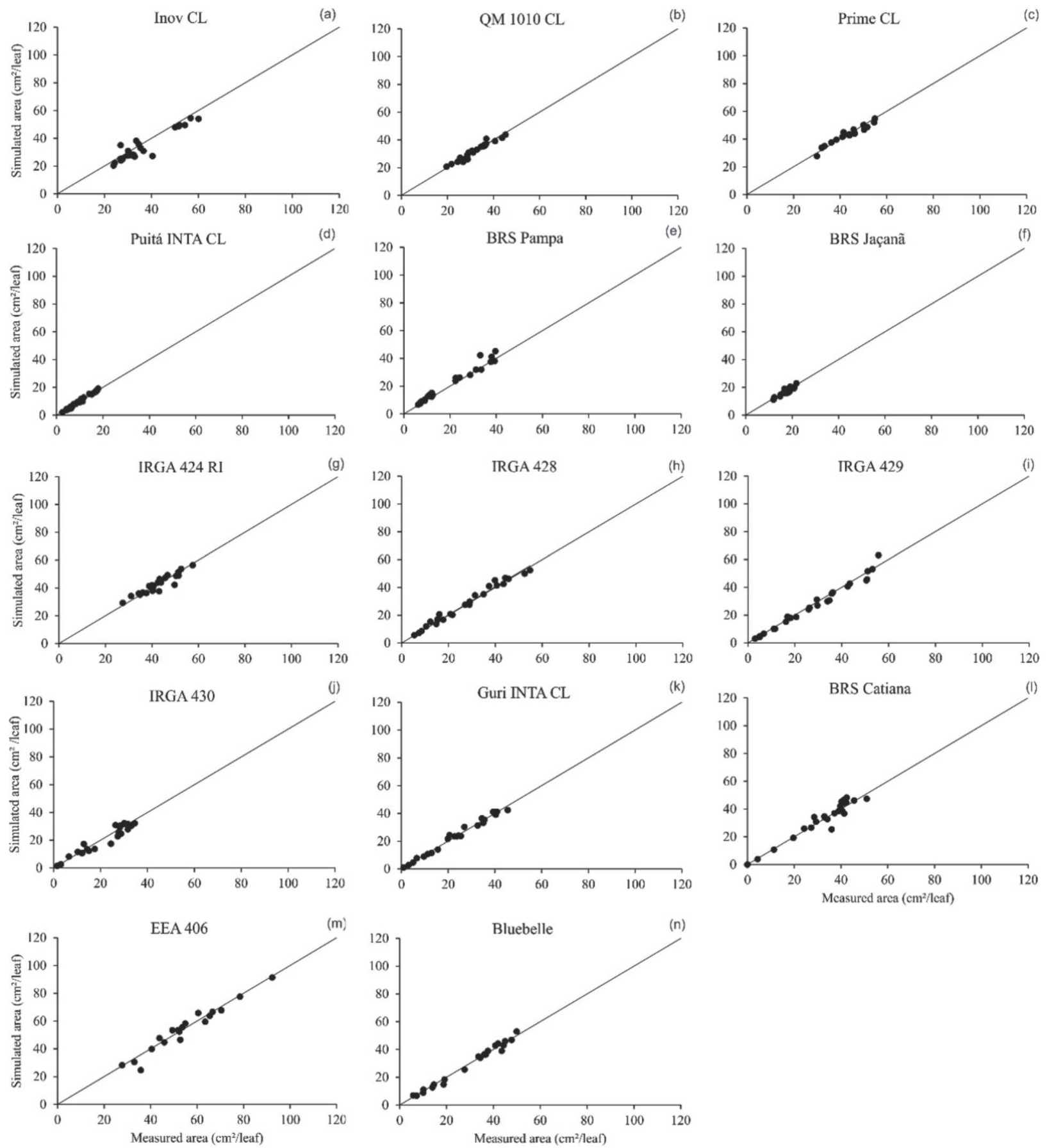

Figure 4: Relationship between leaf area obtained by the software Quant, and LA estimated by leaf dimensions (length and width maximum using specific hybrid coefficient $(\mathrm{a}, \mathrm{b}, \mathrm{c})$ and conventional rice cultivars ( $\mathrm{d}, \mathrm{e}, \mathrm{f}, \mathrm{g}, \mathrm{h}, \mathrm{I}, \mathrm{j}, \mathrm{k}, \mathrm{l}, \mathrm{m}, \mathrm{n})$. The line 1:1 has shown the accuracy between model estimative and measured.

Rev. Ceres, Viçosa, v. 66, n.3, p. 191-199, mai/jun, 2019 
crop growth, increasing during the emergence-flowering phase, when the crop achieved the maximum value, and decreased towards the maturity.

The maximum LAI near flowering is very important for rice crops, as flowering and grain filling stages are the most critical stages for solar radiation interception, as higher amounts of energy intercepted by the canopy during this phase will result in higher yields (Espel et al., 2016). The higher differences between maximum LAI were for Puitá INTA CL cultivar, which was 6.0,9.3 and 7.9 with specific equation and 6.5, 10.0 and 8.5 with general equation sowed in October, November and December, respectively. This difference was attributed to the lower Puitá INTA CL specific coefficient equation $(0.73)$ in relation to general coefficient equation (0.78). There were little differences between estimated LAI with specific and general equation for IRGA 424 RI in three sowing dates and for Guri INTA CL and BRS Pampa in two sowing dates (Figures 5A, 5B and 5D). Through the correlation between leaf dry weight and leaf area, using predetermined ratios between green leaf area and dry leaf mass, found LAI max values for rice ranging from 8.0 to 12.0 in different years (Aschonitis et al., 2014).

The general coefficient $(0.78)$ found in this study was very close from those found in IRRI's Rice Experimental Station, Los Baños, for dry (0.73) and wet season (0.75) (Palaniswamy \& Gomez 1974). Furthermore, estimated coefficient for old semi-draws cultivars in India (0.80) (Bhan \& Pande, 1966) was very close to general coefficient found for modern cultivars in this study. The results found in this study are in agreement with those found in the past 50 years. In other words, similar leaf shape between old and modern cultivars allows to use the general coefficient (0.78) for new cultivars LAI estimation, with no need to estimate new specific coefficients for new cultivars. Due to high labor demand in measure leaf dimensions (length and width) to estimate LAI, we strongly recommend to use the destructive method (dry matter sampling at key stages of development) associated to the general coefficient (0.78), which allows to estimate LAI with high predictive power and few manpower allows to analyze LAI. The highlights of this study may be
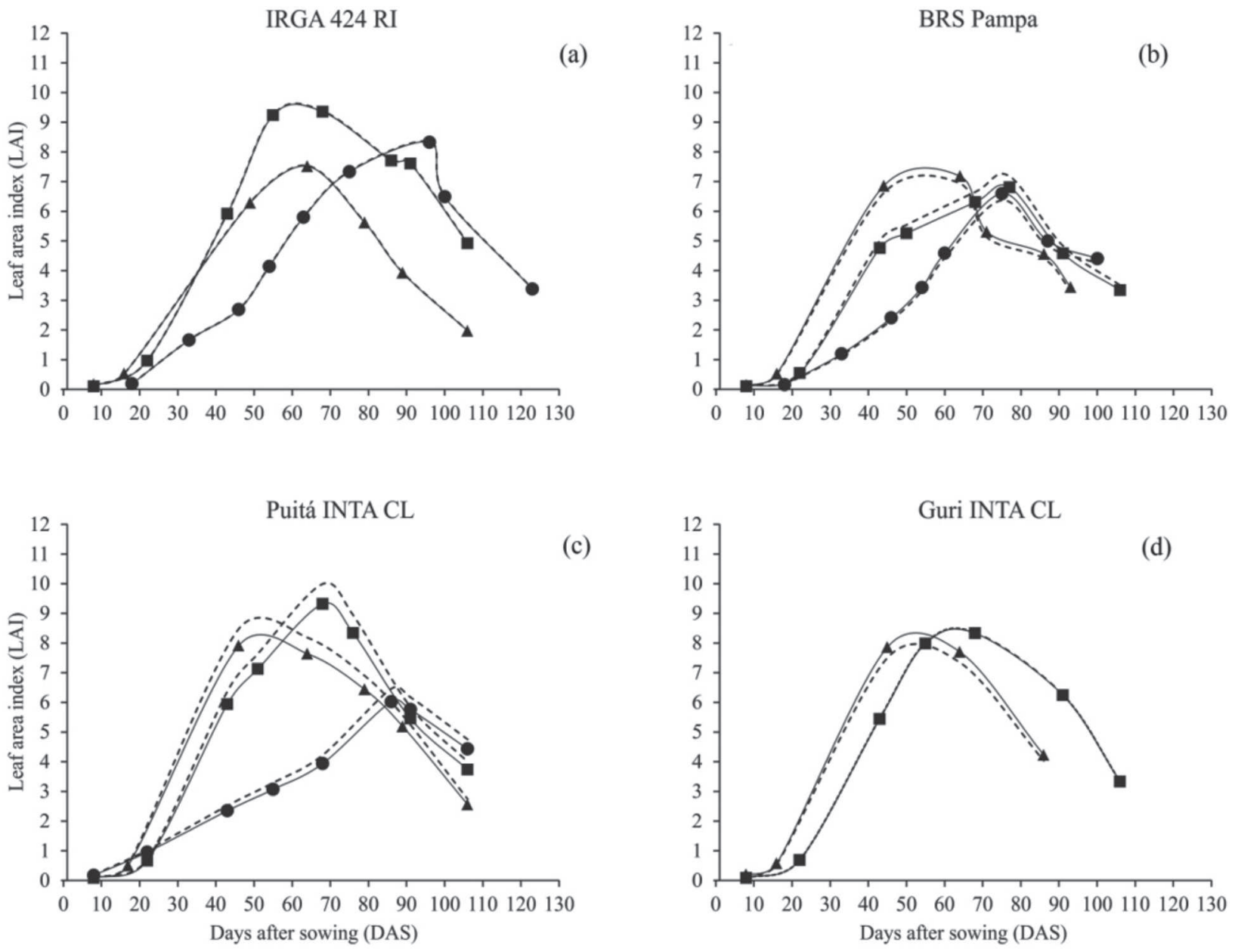

Figure 5: Leaf area index as a function of days after sowing for four rice cultivars in three sowing dates at Cachoeirinha: sowing date 1 (10/01/2015), sowing date $2(11 / 09 / 2015)$ and sowing date $3(12 / 03 / 2015)$. Leaf area was estimated using the cultivar specific equations (solid line) and the general equation for all cultivars (dashed lines). 
Table 2: Statistics for the performance of models for estimating rice leaf area (LA) from leaf dimensions length (L) and width (W) using independent data

\begin{tabular}{|c|c|c|c|c|}
\hline \multicolumn{5}{|c|}{ Statistics } \\
\hline Cultivars & RMSE* & d1* & BIAS* & $\mathbf{r}^{*}$ \\
\hline \multicolumn{5}{|c|}{ Statistics using the cultivar-specific equation } \\
\hline Inov CL & 5.16 & 0.9109 & -0.0171 & 0.9411 \\
\hline QM $1010 \mathrm{CL}$ & 2.19 & 0.8994 & 0.0045 & 0.9324 \\
\hline Prime CL & 2.25 & 0.9750 & -0.0011 & 0.9835 \\
\hline Puitá INTA CL & 0.98 & 0.9669 & 0.0188 & 0.9795 \\
\hline BRS Pampa & 1.63 & 0.9935 & -0.0123 & 0.9958 \\
\hline BRS Jaçanã & 1.23 & 0.9360 & 0.0114 & 0.9601 \\
\hline IRGA 424 RI & 1.47 & 0.9079 & 0.0045 & 0.9384 \\
\hline IRGA 428 & 1.61 & 0.9870 & 0.0042 & 0.9914 \\
\hline IRGA 429 & 1.74 & 0.9911 & 0.0017 & 0.9941 \\
\hline IRGA 430 & 1.46 & 0.9852 & 0.0077 & 0.9902 \\
\hline Guri INTA CL & 2.10 & 0.9852 & -0.0050 & 0.9902 \\
\hline BRS Catiana & 1.53 & 0.9723 & 0.0100 & 0.9818 \\
\hline EEA 406 & 4.61 & 0.9064 & 0.0015 & 0.9369 \\
\hline Bluebelle & 2.05 & 0.9760 & 0.0072 & 0.9842 \\
\hline \multicolumn{5}{|c|}{ Statistics using the general equation $[\mathrm{AF}=0.78(\mathrm{~L} . \mathrm{W})]$} \\
\hline Inov CL & 3.11 & 0.9902 & -0.0652 & 1.0000 \\
\hline QM 1010 CL & 2.24 & 0.8975 & 0.0173 & 0.9324 \\
\hline Prime CL & 3.39 & 0.9654 & -0.0534 & 0.9835 \\
\hline Puitá INTA CL & 1.24 & 0.9608 & -0.0437 & 0.9795 \\
\hline BRS Pampa & 1.89 & 0.9926 & 0.0230 & 0.9958 \\
\hline BRS Jaçanã & 1.29 & 0.9343 & -0.0118 & 0.9601 \\
\hline IRGA 424 RI & 1.47 & 0.9082 & 0.0029 & 0.9384 \\
\hline IRGA 428 & 1.87 & 0.9853 & 0.0363 & 0.9914 \\
\hline IRGA 429 & 2.16 & 0.9893 & 0.0440 & 0.9941 \\
\hline IRGA 430 & 1.77 & 0.9825 & 0.0541 & 0.9902 \\
\hline Guri INTA CL & 2.58 & 0.9823 & 0.0485 & 0.9902 \\
\hline BRS Catiana & 2.18 & 0.9615 & 0.0914 & 0.9818 \\
\hline EEA 406 & 4.72 & 0.9054 & -0.0138 & 0.9369 \\
\hline Bluebelle & 4.23 & 0.9471 & 0.1077 & 0.9842 \\
\hline
\end{tabular}

*RMSE: root mean square error, d1: modified agreement index, BIAS: BIAS index, r: correlation coefficient.

associated to use a remote sensing equipment, such as NDVI readers, in order to validate the method and propose the repair of existing limitations, for example, to validate correlations between the biomass determination methods of destructive form and fracquesas (point of saturation) the index of vegetation of use.

\section{CONCLUSIONS}

The non-destructive method, through the linear dimensions of leaves, is accept to estimate individual leaves area in rice. The general equation is appropriate to be use for modern genotypes in Brazil.

\section{CONFLICT OF INTERESTS}

The authors declared that there is no conflict of interests.

\section{REFERENCES}

Adami M, Hastenreiter FA, Flumignan DL \& Faria RT (2008) Soybean leaflet area estimation using digital imagery and leaf dimensions. Bragantia, 67:1053-1058.

Aschonitis VG, Papamichail DM, Lithourgidis A \& Fano EA (2014) Estimation of Leaf Area Index and Foliage Area Index of Rice using an Indirect Gravimetric Method. Communications in Soil Science and Plant Analysis, 45:1726-1740.

Bakhshandeh E, Kamkar B \& Tsialtas JT (2011) Application of linear models for estimation of leaf area in soybean [Glycine $\max ($ L.) Merr]. Photosynthetica, 49:405-416.

Bhan VM \& Pande HK (1966) Measurement of leaf area of rice. Agronomy Journal, 58:454.

Braga NS, Araujo ACA, Araújo IDA, Souza AAS de, Cunha DS da, Gil VJR, Rocha I de S, Almeida JVS de \& Silva RTL da (2018) Mathematical models for teak foliar area estimation (Tectonas grandis L. F.) Nucleus, 15:331-339. 
Brantley ST, Zinnert JC \& Young DR (2011) Application of hyperspectral vegetation indices to detect variations in high leaf area index temperate shrub thicket canopies. Remote Sensing of Environment, 115:514-523.

Cargnelutti Filho A, Toebe M, Alves BM, Burin C \& Kleinpaul JA (2015) Leaf area estimation of canola by leaf dimensions. Bragantia, 74:139-148.

Espe MB, Cassman KG, Yang H, Guilpart N, Grassini P, Van Wart J, Anders M, Beighley D, Harrell D, Linscombe S, McKenzie K, Mutters R, Wilson LT \& Linquist BA (2016) Yield gap analysis of US rice production systems shows opportuneities for improvement. Field Crops Research, 196:276-283.

Fagundes JD, Streck NA \& Kruse ND (2009) Estimating leaf area of Aspilia montevidensis (Spreng.) Kuntze using linear dimensions. Revista Ceres, 56:266-273.

Hirooka Y, Homma K \& Shiraiwa (2018) Parameterization of the vertical distribution of leaf area index (LAI) in rice (Oryza sativa L.) using a plant canopy analyzer. Scientific reports, $8: 6387$.

Janssen PHM \& Heuberger PSC (1995) Calibration of processoriented models. Ecological Modelling, 83:55-56.

Leite HG \& Andrade VCL (2002) A method for conducting forest inventories without using volumetric equations. Revista Árvore, 26:321-328.

Liu X, Cao Q, Yaun Z, Wang X, Tian Y, Cao W \& Znu Y (2018) Leaf area index based nitrogen diagnosis in irrigated lowland rice. Journal of Integrative Agriculture, 17:111-121.

Jin M, Liu X \& Zhang B (2017) Evaluating Heavy-Metal Stress Levels in Rice Using a Theoretical Model of Canopy-Air Temperature and Leaf Area Index Based on Remote Sensing. IEEE Journal of Selected Topics in Applied Earth Observations \& Remote Sensing PP, 99:01-11.

Maldaner IC, Heldwein AB, Loose LH, Lucas DDP, Guse FI \& Bortoluzzi MP (2009) Models for estimating leaf area in sunflower. Ciência Rural, 39:1356-1361.

Marshall JK (1968) Methods of leaf area measurement of large and small leaf samples. Photosynthetica, 2:41-47.

Palaniswamy KM \& Gomez KA (1974) Length-width method for estimating leaf area of rice. Agronomy Journal, 66:430-3.

Ribas GG, Streck NA, Lago I, Zanon AJ, Waldow DAG, Junior AJD, Nascimento M de F do \& Fontana V (2017) Accumulated dry matter and grain yield in flooded hybrid rice simulated with the SimulArroz model. Pesquisa Agropecuária Brasileira 51:19071917.
Richter GL, Zanon AJ, Streck NA, Guedes JVC, Kräulich B, Rocha TSM, Winck JEM \& Cera JC (2014) Estimating leaf area of modern soybean cultivars by a non-destructive method. Bragantia, 73:416-425.

Samboranha FK, Streck NA, Uhlmann LO \& Gabriel LF (2013) Mathematical modeling of leaf development in the cassava. Revista Ciência Agronômica, 44:815-824.

Schwab NT, Streck NA, Rehbein A, Ribeiro BSMR, Ulhmann LO, Langner JA \& Becker CC (2014) Linear dimensions of leaves and its use for estimating the vertical profile of leaf area in gladiolus. Bragantia, 73:97-105.

Silveira P (1985) Melhoramento genético: outro fator decisivo na produtividade do arroz gaúcho. Revista Lavoura Arrozeira, 58:01-11.

Taiz L \& Zeiger E (2013) Fisiologia vegetal. Porto Alegre, Artmed. 954p.

Tanaka A \& Kawano K (1965) Leaf Characters Relating to Nitrogen Response in the Rice Plant. Soil Science and Plant Nutrition, 11:31-38.

Van Ittersum MK, Cassman KG, Grassini P, Wolf J, Tittonell P \& Hochman Z (2013) Yield gap analysis with local to global relevance - a review. Field Crop Research, 143:04-17.

White MA, Asner GP, Nemani RR, Privette JL \& Running SW (2000) Measuring fractional cover and leaf area index in arid ecosystems: Digital camera, radiation transmittance, and laser altimetry methods. Remote Sensing of Environment, 74:4557.

Willmott CJ, Ackleson SG, Davis JJ, Feddema KM \& Klink DR (1985) Statistics for the evaluation and comparison of models. Journal of Geophysical Research, 90:8995-9005.

Xiao X, He L, Salas W, Li C, Moore B, Zhao R, Frolking S \& Boles S (2002) Quantitative relationships between field-measured leaf area index and vegetation index derived from vegetation images for paddy rice fields. International Journal of Remote Sensing, 23:3595-3604.

Yang Y, Zhang M, Xu Q, Feng Y, Yuan X, Yu H \& Wei X (2018) Exploration of genetic selection in rice leaf length and width. Botany, 96:249-256. 